ISEC2005-76231

\title{
EVALUATION OF A HIGH-PERFORMANCE SOLAR HOME IN LOVELAND, COLORADO
}

\author{
Robert Hendron \\ National Renewable Energy Laboratory \\ Golden, CO
}

\author{
Mark Eastment \\ National Renewable Energy Laboratory \\ Golden, CO
}

\author{
Ed Hancock \\ Mountain Energy Partnership \\ Boulder, CO
}

\author{
Greg Barker \\ Mountain Energy Partnership \\ Boulder, $\mathrm{CO}$
}

\author{
Paul Reeves \\ Partnership for Resource Conservation \\ Boulder, CO
}

\begin{abstract}
Building America (BA) partner McStain Neighborhoods built the Discovery House in Loveland, Colorado, with an extensive package of energy-efficient features, including a high-performance envelope, efficient mechanical systems, a solar water heater integrated with the space-heating system, a heat-recovery ventilator (HRV), and ENERGY STAR ${ }^{\mathrm{TM}}$ appliances.

The National Renewable Energy Laboratory (NREL) and Building Science Consortium (BSC) conducted short-term field-testing and building energy simulations to evaluate the performance of the house. These evaluations are utilized by BA to improve future prototype designs and to identify critical research needs.

The Discovery House building envelope and ducts were very tight under normal operating conditions. The HRV provided fresh air at a rate of about $75 \mathrm{cfm}(35 \mathrm{l} / \mathrm{s})$, consistent with the recommendations of ASHRAE Standard 62.2. The solar hot water system is expected to meet the bulk of the domestic hot water (DHW) load ( $>83 \%$ ), but only about $12 \%$ of the space-heating load. DOE-2.2 simulations predict wholehouse source energy savings of 54\% compared to the BA Benchmark [1]. The largest contributors to energy savings beyond McStain's standard practice are the solar water heater, HRV, improved air distribution, high-efficiency boiler, and compact fluorescent lighting package.
\end{abstract}

\section{NOMENCLATURE}

$\begin{array}{ll}\text { ACH } & \text { Air changes per hour } \\ \text { AFUE } & \text { Annual fuel utilization efficiency } \\ \text { AH } & \text { Air Handler } \\ \text { BA } & \text { Building America } \\ \text { CAE } & \text { Combined annual efficiency } \\ \text { DHW } & \text { Domestic hot water } \\ \text { EF } & \text { Energy factor }\end{array}$

$\begin{array}{ll}\text { HRV } & \text { Heat recovery ventilator } \\ \text { RMC } & \text { Remaining moisture content } \\ \text { SEER } & \text { Seasonal energy efficiency ratio } \\ \text { SHGC } & \text { Solar heat gain coefficient } \\ \text { TRNSYS } & \text { TRaNsient SYstems Simulation }\end{array}$

\section{INTRODUCTION}

Building America is a partnership between the U.S. Department of Energy (DOE) and the building industry to develop production-ready building systems that lead to wholehouse energy savings of $50 \%$ by 2010 and $90 \%$ by 2020 . McStain Neighborhoods is a partner to BSC, one of five Building America industry teams. Targeting 40-50\% energy savings, McStain and BSC designed and built the Discovery House in Loveland, Colorado, with a large number of energyefficiency measures. In addition to a high-performance envelope and efficient mechanical systems, this home utilizes a passive solar design, a solar hot water loop integrated with the space-heating system, an HRV, compact fluorescent lighting, and energy-efficient appliances. In June 2004, NREL worked in partnership with McStain and BSC to provide comprehensive field-testing and analysis to evaluate key building systems and identify possible solutions to any performance issues. Figure 1 shows the completed house at the time field-testing was conducted. The Discovery House is a $2512-\mathrm{ft}^{2}\left(233-\mathrm{m}^{2}\right)$, two-story home with a $636-\mathrm{ft}^{2}\left(59-\mathrm{m}^{2}\right)$ conditioned basement. Other key design specifications are summarized in Table 1. Features that are not part of McStain's standard practice in the Denver metropolitan area are presented in italics. For this particular project, NREL began its participation after the design and construction had been completed. A more complete description of the Discovery House and the design philosophy behind it can be found in an article published by McStain Neighborhoods [2]. 


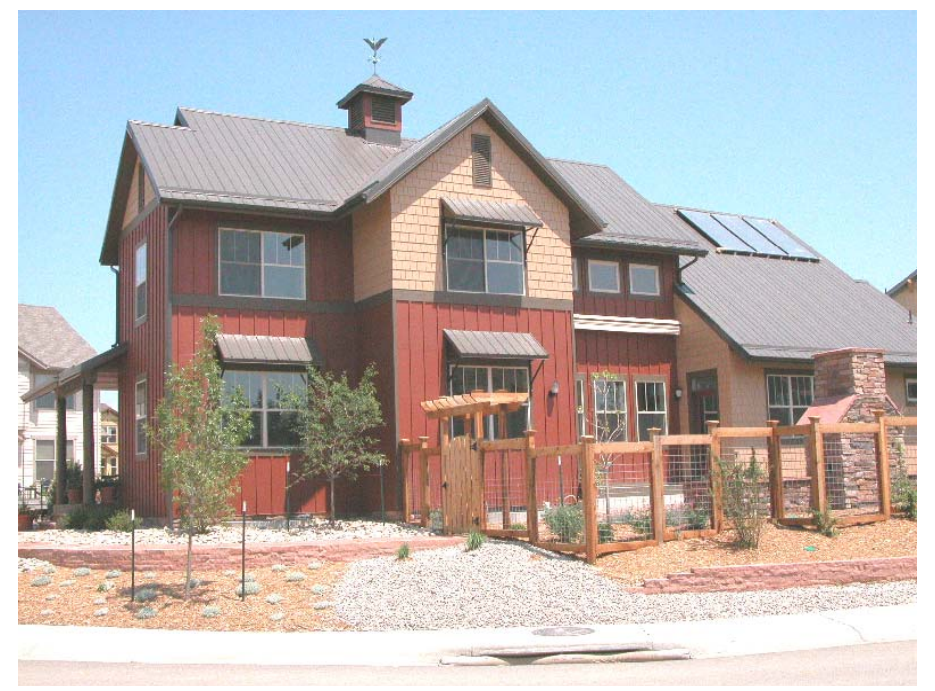

Figure 1. McStain Discovery House (view from south)

Table 1. McStain Discovery House Key Specifications

\begin{tabular}{|c|c|}
\hline Ceiling & R-44+ dry-blown cellulose \\
\hline Walls & $\begin{array}{l}\text { 2x6 24-in (61-cm) on-center (oc), R-19 damp- } \\
\text { spray cellulose insulation and } R-4 \text { 3/4-in (1.9- } \\
\mathrm{cm}) \text { Dow XPS, 7/16-in }(1.1-\mathrm{cm}) \text { OSB exterior, } \\
\text { MemBrain interior; } \\
\mathrm{R}-19 \text { cellulose } 2 \times 6 \text { 24-in }(61-\mathrm{cm}) \text { oc to garage }\end{array}$ \\
\hline $\begin{array}{l}\text { Basement } \\
\text { walls }\end{array}$ & $\begin{array}{l}\text { Fiberglass batts with vinyl facers draped on } \\
\text { walls }(R-11)\end{array}$ \\
\hline $\begin{array}{l}\text { Basement } \\
\text { slab }\end{array}$ & $\begin{array}{l}\text { 1-in }(2.5-\mathrm{cm}) X P S(R-5) \text { and } 6 \text {-in }(15-\mathrm{cm}) \text { EPS } \\
\text { void material }(\sim R-1.2) \text {, radiant slab heating }\end{array}$ \\
\hline $\begin{array}{l}\text { Windows } \\
\text { and } \\
\text { Skylights }\end{array}$ & $\begin{array}{l}\text { Vinyl frame, Low-E, spectrally selective } \\
\text { double-glazing, } \mathrm{U}=0.35, \mathrm{SHGC}=0.34 \text {, } \\
\text { movable awnings, thermostatically-controlled } \\
\text { motorized windows }\end{array}$ \\
\hline $\begin{array}{l}\text { Space } \\
\text { Heating }\end{array}$ & $\begin{array}{l}\text { Lennox CompleteHeat in basement, } 100 \\
\mathrm{kBtu} / \mathrm{hr}(29 \mathrm{~kW}), 0.90 \mathrm{CAE}, \text { solar assisted }\end{array}$ \\
\hline $\begin{array}{l}\text { Space } \\
\text { Cooling }\end{array}$ & $\begin{array}{l}\text { Lennox 19.2 SEER split system, two Tamarac } \\
\text { 1000-cfm whole-house fans, manual control }\end{array}$ \\
\hline DHW & $\begin{array}{l}\text { Lennox CompleteHeat, } 0.90 \text { CAE, } 100 \mathrm{kBtu} / \mathrm{hr} \\
(29 \mathrm{~kW}), 34 \text {-gallon tank, solar assisted, } \\
\text { drainback system, three } 4 x 8 \text { collectors, 180-gal } \\
\text { solar tank, recirculation loop on timer }\end{array}$ \\
\hline Ducts & $\begin{array}{l}\text { Uninsulated metal with mastic in basement, } \\
\text { floor joist spaces, and interior walls; fully } \\
\text { ducted returns (first and second floors) }\end{array}$ \\
\hline Ventilation & $\begin{array}{l}\text { Lennox HRV2-150 HRV, } 123 \text { CFM }(58 \mathrm{l} / \mathrm{s}), 60- \\
66 \% \text { sensible effectiveness, fan-cycling control } \\
\text { for intermittent mixing, temperature-controlled } \\
\text { window operation }\end{array}$ \\
\hline Other & $\begin{array}{l}\text { Compact fluorescent lighting (CFL) package } \\
\text { and ENERGY STAR appliances (weight sensing } \\
\text { horizontal axis clothes washer, soil sensing } \\
\text { dishwasher, dryer with temperature and } \\
\text { moisture feedback) }\end{array}$ \\
\hline
\end{tabular}

\section{SHORT-TERM FIELD TEST RESULTS}

Building envelope and duct leakage tests were conducted by BSC personnel using a blower door and duct blaster. A summary of the measurements, which are not adjusted for high altitude, is shown in Table 2.

Table 2. Air Leakage Characteristics Measured by BSC

\begin{tabular}{|r|r|c|}
\hline $\begin{array}{r}\text { Blower } \\
\text { Door }\end{array}$ & CFM50 (1/s) & $1052(497)$ \\
& ${\text { Estimated } \text { ACH }_{\text {nat }}}$ & 0.163 \\
\hline $\begin{array}{r}\text { Duct } \\
\text { Blaster }\end{array}$ & CFM25 $_{\text {total }}(1 / \mathrm{s})$ & $365(172)$ \\
& CFM25 $_{\text {outside }}(1 / \mathrm{s})$ & $21(10)$ \\
& CFM25 $_{\text {total, supply }}(1 / \mathrm{s})$ & $289(137)$ \\
& CFM25 $_{\text {outside, supply }}(1 / \mathrm{s})$ & $20(9)$ \\
\hline
\end{tabular}

These measurements verified compliance with the BSC air-leakage specifications of less than 2239 CFM50 (1057 l/s @,50 $\mathrm{Pa})$, or $2.5 \mathrm{in}^{2}\left(16 \mathrm{~cm}^{2}\right)$ EqLA per $100 \mathrm{ft}^{2}\left(9.3 \mathrm{~m}^{2}\right)$ of surface area, and less than 5\% duct leakage to the outside, corresponding to $60 \mathrm{cfm}(28 \mathrm{l} / \mathrm{s})$ based on $1200 \mathrm{cfm}(566 \mathrm{l} / \mathrm{s})$ total airflow. The design target of $10 \%$ total duct leakage, or $120 \mathrm{cfm}(57 \mathrm{l} / \mathrm{s})$, was not met during initial testing, but additional air-sealing steps taken by the builder reduced duct leakage from $289 \mathrm{cfm}(136 \mathrm{l} / \mathrm{s})$ to about $135 \mathrm{cfm}(64 \mathrm{l} / \mathrm{s})$ on the supply side, which is very close but still would not quite meet the target level of $120 \mathrm{cfm}(57 \mathrm{l} / \mathrm{s})$ total.

The NREL multi-zone tracer-gas monitoring system was installed in the Discovery House from June 13 to 17, with sample points on each floor, including the basement. Air exchange rates were measured for several different operating conditions, with and without the air-handler fan and HRV operating. The measured hourly average air exchange rates are displayed in Figure 2. The outside temperature during the test period was fairly mild and peaked as high as $95^{\circ} \mathrm{F}\left(35^{\circ} \mathrm{C}\right)$ on some days while remaining below $60^{\circ} \mathrm{F}\left(16^{\circ} \mathrm{C}\right)$ on other days (usually when overcast). Active space conditioning was unnecessary and was not employed during the test period.

From 1800 h Sunday, June 13, through 0700 h Monday, June 14, the house was in normal operating mode with the HRV on at low speed and the air-handler operating continuously. The measured air exchange rate during this period was between 0.15 and 0.20 air changes per hour $(\mathrm{ACH})$, depending on wind speed and temperature difference. The HRV was turned off at $0800 \mathrm{~h}$ on Monday, turned on again at $1400 \mathrm{~h}$ and off again at $1800 \mathrm{~h}$. This is commonly referred to as a "bump" test. The difference between the on and off periods was about $0.12-0.13 \mathrm{ACH}(69-75 \mathrm{cfm}$, or $33-35 \mathrm{l} / \mathrm{s})$ and represents the net air exchange attributable to operation of the HRV. Another bump test was performed on June 16 with similar results. From $1800 \mathrm{~h}$ Monday until $0800 \mathrm{~h}$ Wednesday, the house operated without ventilation. The measured airexchange rate without ventilation was between 0.02 and 0.05 $\mathrm{ACH}$. Additional ventilation was clearly an important and necessary feature of this house. The design ventilation rate for the HRV was $75 \mathrm{cfm}(35 \mathrm{l} / \mathrm{s})$ at low speed and $175 \mathrm{cfm}(83 \mathrm{l} / \mathrm{s})$ at high speed. Based on a conditioned floor area of $3148 \mathrm{ft}^{2}$ (292 $\mathrm{m}^{2}$ ), including a basement and three bedrooms, the ventilation rate recommended by ASHRAE Standard 62.2 is 75 $\operatorname{cfm}(351 / \mathrm{s})$. The design target appears to have been met within the accuracy of the tracer gas measurements. 
The air handler (AH) was turned off from $0800 \mathrm{~h}$ on Tuesday, June 15, until $0800 \mathrm{~h}$ on Wednesday, June 16. The effect on ACH was negligible, perhaps 0.01-0.02 ACH (6-12 $\mathrm{cfm}$, or 3-6 1/s). This is consistent with our expectations for ducts located in conditioned space and is also consistent with the duct blaster results measured by BSC (21 cfm, or 10 1/s @ $25 \mathrm{~Pa})$.

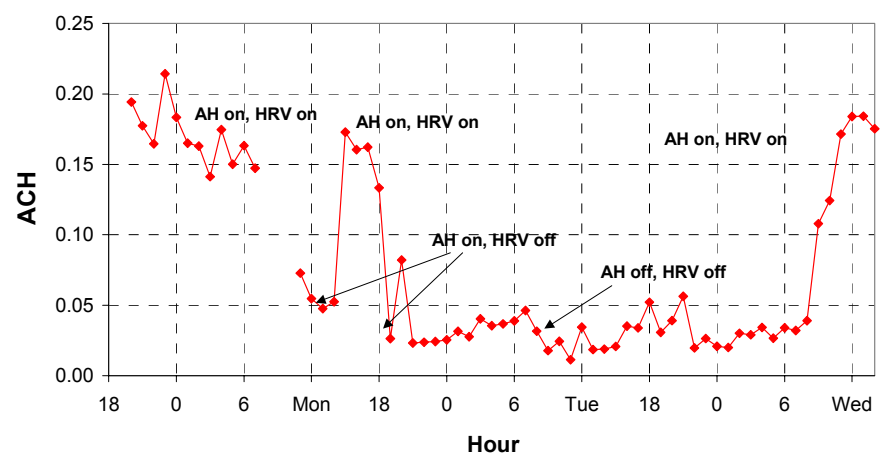

Figure 2. Tracer gas measurements at the Discovery House

The interior temperatures of the house during the test period are shown in Figure 3. Because the heating and cooling functions were not active during the test period, these profiles show that the air was well mixed during the tracer gas test. In addition, the energy efficiency measures appeared to be effective in keeping the interior temperature stable during mild weather conditions without the need for space conditioning.

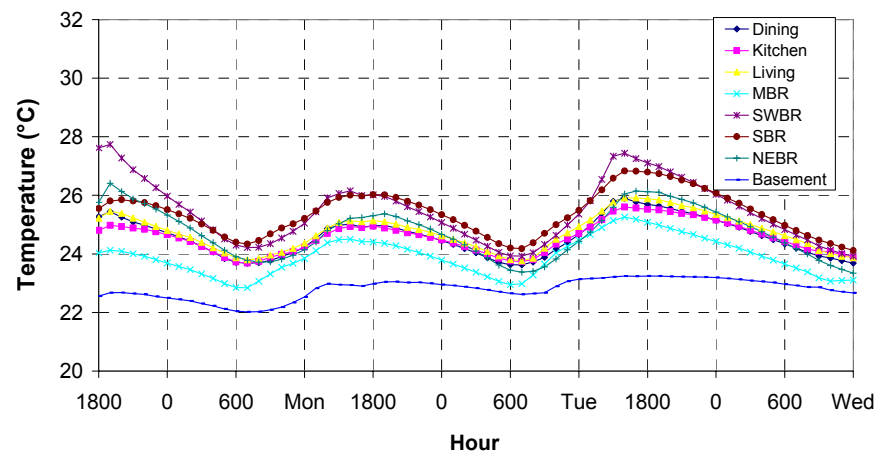

Figure 3. Interior temperatures during the first week of shortterm testing

Three of the energy-efficient appliances (dishwasher, clothes washer, clothes dryer) used in the Discovery House were evaluated as part of this test. Because occupant behavior can have such a large effect on energy and hot water use for these appliances, NREL was interested in characterizing their performance beyond the basic information provided on the EnergyGuide labels. Energy savings calculations for the appliances in both the Discovery House and the BA Benchmark are based on the 2005 version of an appliance analysis spreadsheet developed by NREL [3]. This spreadsheet performs energy-savings calculations using the energyconsumption data collected by the manufacturer in accordance with the DOE standard test procedures $[4,5,6]$. Usually these data can be found on the EnergyGuide label, the manufacturer's web site, the ENERGY STAR web site (www.energystar.gov/index.cfm?c=appliances.pr_appliances), or in the appliance database published by the California Energy Commission (www.energy.ca.gov/appliances/appliance). The NREL spreadsheet accepts published test results as inputs and calculates energy and hot-water consumption for the Prototype and Benchmark based on the operating conditions and analysis guidelines documented in the BA Benchmark Definition [1].

Energy savings predictions for these three energy-efficient appliances are provided in Table 3. The results suggest that substantial end-use energy savings can be expected for all three appliances. Electricity, natural gas, and hot water usage are all significantly less than the Benchmark values.

Table 3. Energy Savings Calculations for Discovery House Appliances (Pre-test)

\begin{tabular}{|l|c|c|c|}
\hline & $\begin{array}{c}\text { Dish- } \\
\text { washer }\end{array}$ & $\begin{array}{c}\text { Clothes } \\
\text { Washer }\end{array}$ & $\begin{array}{c}\text { Clothes } \\
\text { Dryer }\end{array}$ \\
\hline $\begin{array}{l}\text { Benchmark Electricity } \\
\text { (kWh/yr) }\end{array}$ & 240 & 122 & 89 \\
\hline $\begin{array}{l}\text { Discovery House Electricity } \\
\text { (kWh/yr) }\end{array}$ & 102 & 41 & 73 \\
\hline$\%$ Electricity Savings & $58 \%$ & $66 \%$ & $18 \%$ \\
\hline Benchmark Gas (kWh/yr) & N/A & N/A & 1817 \\
\hline $\begin{array}{l}\text { Discovery House Gas } \\
\text { (kWh/yr) }\end{array}$ & N/A & N/A & 850 \\
\hline$\%$ Gas Savings & N/A & N/A & $53 \%$ \\
\hline Benchmark DHW (liters/day) & 22.0 & 66.2 & N/A \\
\hline $\begin{array}{l}\text { Discovery House DHW } \\
\text { (liters/day) }\end{array}$ & 8.7 & 19.3 & N/A \\
\hline$\%$ DHW Savings & $60 \%$ & $71 \%$ & N/A \\
\hline
\end{tabular}

The clothes washer in the Discovery House was an ENERGY STAR-rated Whirlpool Duet Model GHW9200LT1. This model is a $3.18-\mathrm{ft}^{3}\left(0.09-\mathrm{m}^{3}\right)$ horizontal-axis machine with a thermostatic control valve to adjust the ratio of hot and cold water entering the tub, an internal heater to boost the hot-water temperature for the "sanitary" cycle, and a weight sensor to adjust water level based on the size of the load. The washer was run with $3 \mathrm{lb}(1.4 \mathrm{~kg})$ and $7 \mathrm{lb}(3.2 \mathrm{~kg})$ test loads using each of the five available wash/rinse cycles (cold/cold, warm/cold, warm/warm, hot/cold, extra hot/cold). This series of tests was intended to duplicate as nearly as possible the DOE standard appliance test procedures, used as the basis for calculating the information published on the EnergyGuide label. The test loads consisted of clean white $100 \%$ cotton tshirts; laundry detergent was not used.

The measured hot water and machine energy use during the tests are shown in Figures 4 and 5. All test cycles consumed significantly less hot water than the BA Benchmark, and all of the cycles except the sanitary wash cycle (extra hot/cold) used less machine energy. (In fact, the sanitary cycle not only used a large amount of energy to heat the water to about $150^{\circ} \mathrm{F}\left(66^{\circ} \mathrm{C}\right)$, but the cycle duration exceeded 2 hours.) As expected, the automatic water-level control feature significantly reduced the amount of hot water consumption when the smaller $3 \mathrm{lb}(1.4 \mathrm{~kg})$ test load was used. Also evident is the significant difference in hot water use for both cold washing and cold rinsing. However, it is noteworthy that this machine actually did use a small amount of hot water during 
the cold wash cycle to maintain a temperature of about $70^{\circ} \mathrm{F}$ $\left(21^{\circ} \mathrm{C}\right)$ for the purpose of detergent activation.

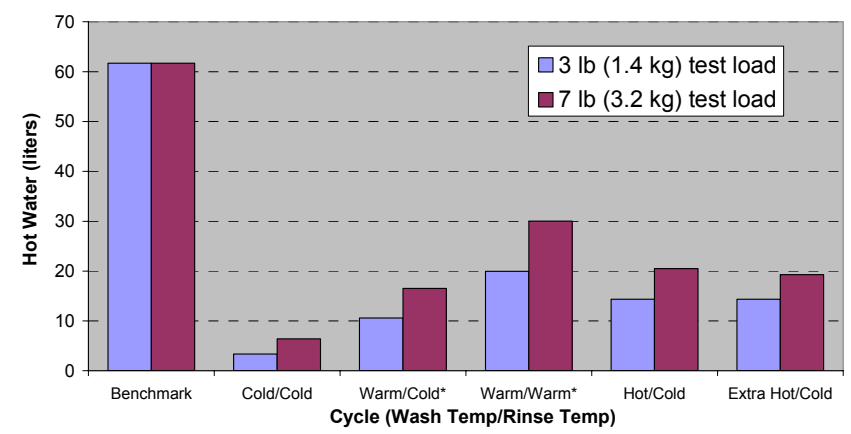

Figure 4. Clothes washer hot water use under various operating conditions. Extra rinse used for Warm/Cold and $3 \mathrm{lb}(1.4 \mathrm{~kg})$ Warm/Warm cycles.

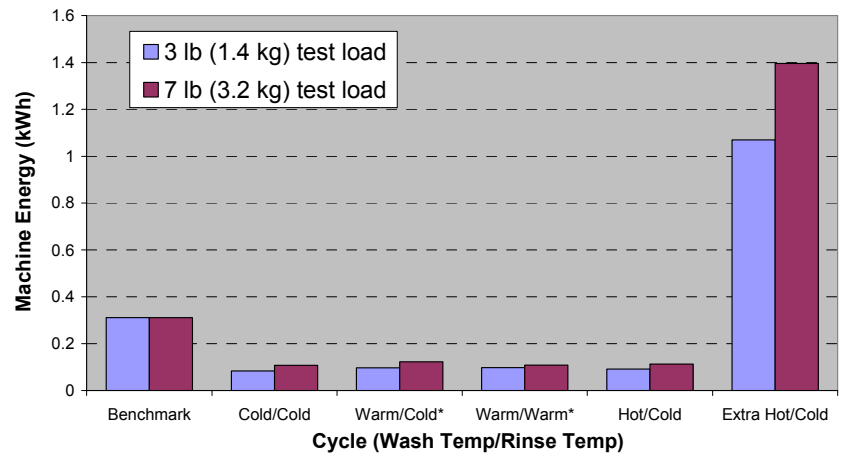

Figure 5. Clothes washer machine energy use under various operating conditions. Extra rinse used for Warm/Cold and $3 \mathrm{lb}$ $(1.4 \mathrm{~kg}) \mathrm{Warm} /$ Warm cycles.

The clothes dryer in the Discovery House was a Whirlpool Duet Model GGW9200L. Dryers do not have EnergyGuide labels and cannot qualify for ENERGY STAR. However, this dryer does have moisture and temperature sensors designed to reduce drying time and save energy by optimizing the amount of heat added and by automatically turning off the dryer when the clothes are dry. In addition, the ENERGY STAR clothes washer was expected to yield indirect energy savings for the dryer by reducing the remaining moisture content (RMC) in the clothes at the end of the spin cycle. RMC is defined as the weight of the water remaining in the damp clothes after the wash cycle divided by the dry weight.

Figures 6 and 7 present dryer electricity and natural gas use corresponding to the five clothes washer test cycles discussed above. Unfortunately, electricity data for one of the $3 \mathrm{lb}(1.4$ $\mathrm{kg}$ ) cycles were accidentally overwritten following the test, and could not be reported. Energy use was substantially less than the Benchmark value for nearly all of the test cycles. However, the drying times did not seem to be faster than usual, averaging 30 minutes for the $3 \mathrm{lb}(1.4 \mathrm{~kg})$ loads and 40 minutes for the 7 lb $(3.2 \mathrm{~kg})$ loads. In fact, several $12.9 \mathrm{lb}(5.9 \mathrm{~kg})$ loads (full loads according to the DOE test procedures) were run, and the drying times averaged about 90-120 minutes. One of the 7-lb $(1.4 \mathrm{~kg})$ loads used much more machine energy than the others and tended to cycle on and off much more frequently. There was no clear explanation suggested by the data, so the unusually high dryer energy was likely caused by an anomaly in the dryer load, such as bunching or some other random effect.

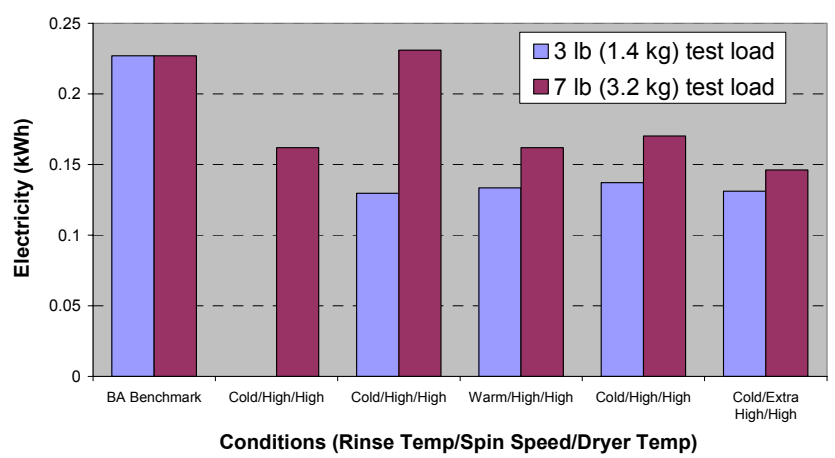

Figure 6. Clothes dryer electricity use under various operating conditions

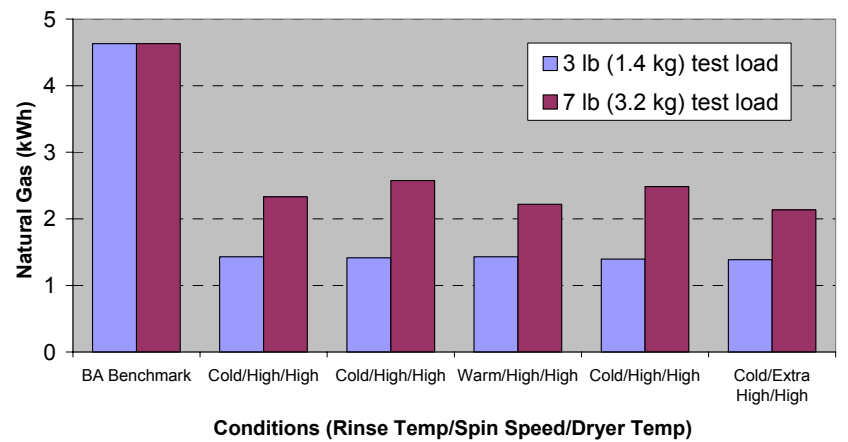

Figure 7. Clothes-dryer natural gas use under various operating conditions

The dishwasher installed in the test house was an ENERGY STAR-rated Whirlpool GU1200XTLT3. Features of this model include five different wash levels, a soil sensor that adjusts wash time based on the dirtiness of the dishes, and a heated drying option. The dishwasher was operated using a test load consisting of eight place settings of typical ceramic dishes and stainless steel silverware. Most cycles were run with clean dishes. For cycles with dirty dishes, a controlled amount of spaghetti sauce was brushed on the dishes, which were then cooked in the microwave for about 20 seconds to simulate the effects of a typical meal.

The electricity and hot water use of the dishwasher under a variety of operating conditions are summarized in Figure 8. The dishwasher used less energy than the BA Benchmark for both the machine and hot water under each of the conditions tested. However, the results indicate that the electric heaters used in the power dry option nearly double the amount of machine electrical energy compared to the air-dry option. The data also suggest that the soil sensor has a very large effect on both the hot water use and the machine energy. Ultimately, user-controlled operating choices will determine whether this ENERGY STAR dishwasher saves energy compared to a typical dishwasher. 


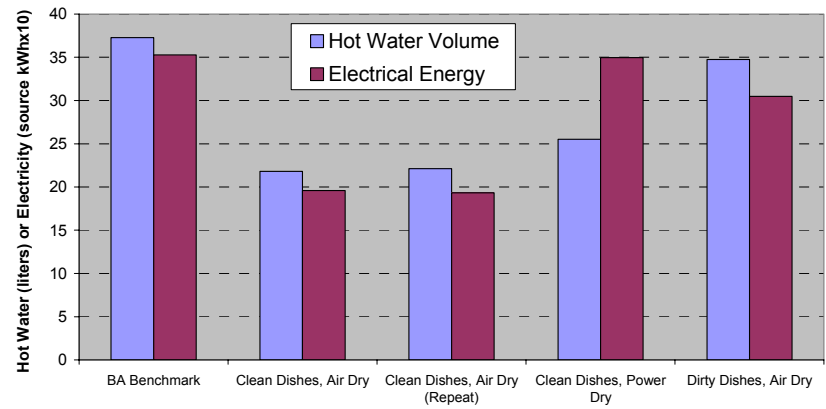

Figure 8. Dishwasher electricity and hot water consumption under various test conditions

\section{SOLAR WATER HEATER}

TRNSYS simulations were performed to evaluate the contribution of the solar hot water system toward meeting the DHW and space-heating loads. A schematic of the hot water system in the Discovery House is shown in Figure 9. The thermostat on the solar storage tank controls two solenoid valves wired in parallel, one normally open and one normally closed. When the storage tank temperature is above the thermostat setting (currently $110^{\circ} \mathrm{F}$, or $43^{\circ} \mathrm{C}$ ) and if either space heat through the air handler heating coil or space heat through the hydronic floor in the basement is called for, the respective circulation loop will be directed through the solar storage tank to collect heat. If the storage tank is not hot enough then the loop will be directed through the boiler to collect heat.

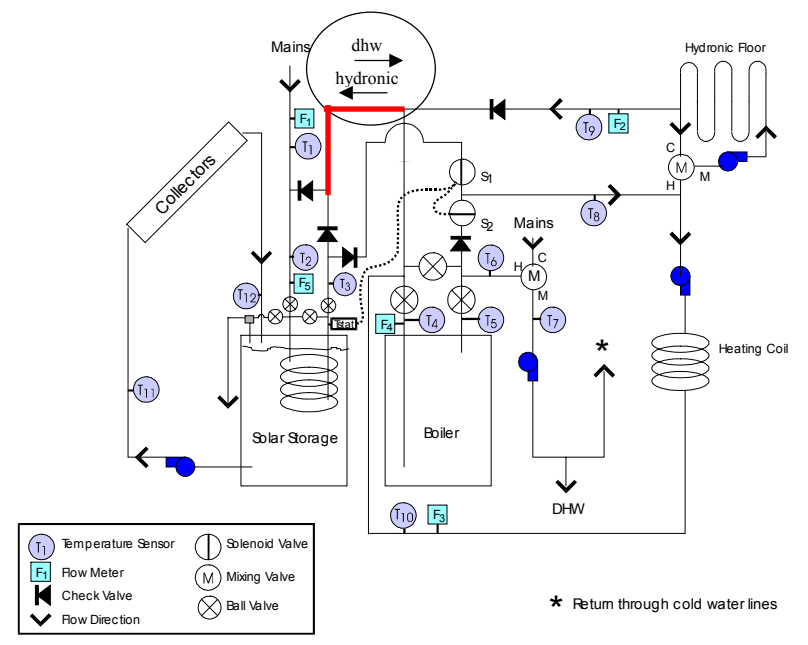

Figure 9. Schematic design of domestic hot water and spaceheating system

There are limitations to using the solar storage tank as a source for DHW, space heat through the air handler, and space heat through the hydronic floor. The heating coil in the air handler is typically designed to deliver the expected heating energy using a circulating water temperature of $120^{\circ} \mathrm{F}\left(49^{\circ} \mathrm{C}\right)$ or higher. If the temperature is lower, then the heat exchange rate at the air handler coil may be too low to meet the load. The hydronic loop, on the other hand, can deliver heat at a lower temperature, perhaps $90^{\circ} \mathrm{F}\left(32^{\circ} \mathrm{C}\right)$. With the system as it is now, the thermostat on the storage tank must be set to about $110^{\circ} \mathrm{F}\left(43^{\circ} \mathrm{C}\right)$ to be able to meet the load at the air handler.
Because there is also a load on the storage tank to heat DHW, the tank will rarely reach $110^{\circ} \mathrm{F}\left(43^{\circ} \mathrm{C}\right)$ and, therefore, only a small fraction of the space-heating load is likely to be met by solar energy.

Figures 10 and 11 show the predicted contribution of the solar storage tank toward each end-use, based on the DHW volume and operating profile specified for Building America analysis [7]. Figure 10 shows the results for the system as installed, and Figure 11 shows the effect of reducing the minimum supply temperature for the hydronic floor slab to $90^{\circ} \mathrm{F}\left(32^{\circ} \mathrm{C}\right)$, and disconnecting the heating coil loop from the solar tank. In either case, the solar hot water system is expected to meet a very large percentage of the DHW load ( $83 \%$ as-built, $77 \%$ if modified), which for the purpose of this analysis includes both the energy to heat the mains water to the set point of $120^{\circ} \mathrm{F}\left(49^{\circ} \mathrm{C}\right)$ and the standby losses associated with the boiler tank. Based on our analysis, it appears that a greater fraction of the combined DHW and space-heating loads can be met by making the system modifications. We would expect the fraction of the basement space-heating load met by the solar system to increase from about $25 \%$ to nearly $56 \%$. This would represent an increase from $12 \%$ to $16 \%$ of the total spaceheating load, and an increase from $28 \%$ to $30 \%$ of the combined DHW and space-heating loads.

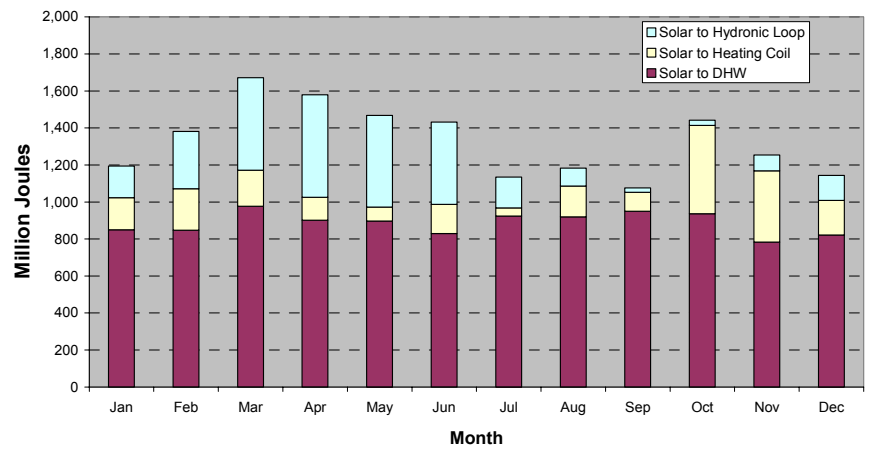

Figure 10. TRNSYS simulation results for the solar hot water system as currently implemented

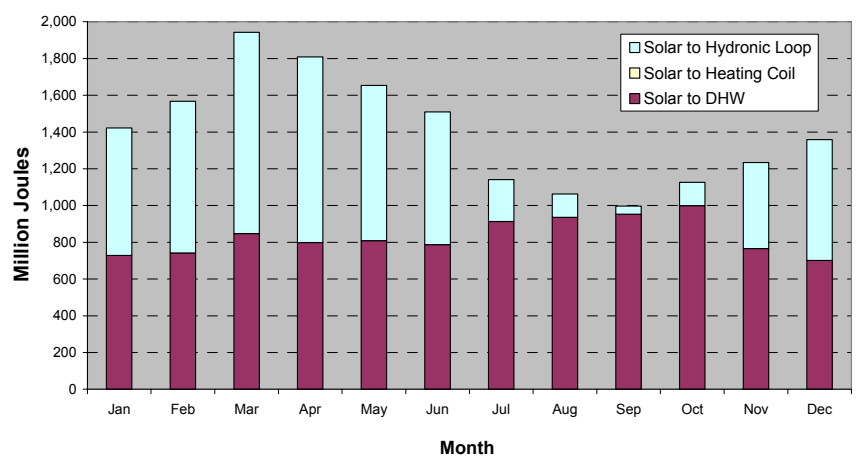

Figure 11. TRNSYS results if heating coil water does not run through the solar storage tank and the minimum supply temperature for the solar storage tank is set to $90^{\circ} \mathrm{F}\left(32^{\circ} \mathrm{C}\right)$

It is important to note that for Loveland, Colorado, an idiosyncrasy in the BA analysis guidelines results in active space heating throughout the year with a set point of $71^{\circ} \mathrm{F}$ 
$\left(22^{\circ} \mathrm{C}\right)$, which is the optimal temperature for the average person when the house is in heating mode. This is an unlikely operating condition during the summer months even in cold climates. For the Discovery House, combining this year-round heating set-point with night ventilation, cool night-time temperatures at high altitude, relatively small internal heat gains, and reduced DHW demand, the analysis predicts what may be an unrealistically high solar contribution toward summertime space heating.

During short-term testing of the solar hot water system, two performance issues became apparent. The system did not always begin circulating water to the collector when weather conditions indicated it should, and the system was short cycling once it got started. The short cycling problem was traced to an oversized pump, which was circulating too much flow (about 6 $\mathrm{gpm}$, or $0.38 \mathrm{l} / \mathrm{s}$ ) to the collector, resulting in a temperature rise that was too small. This issue was partly corrected by adjusting a valve to increase the pressure head, thereby reducing the flow rate to a more reasonable level (about $2 \mathrm{gpm}$, or $0.13 \mathrm{l} / \mathrm{s}$ ). As a longer-term solution, NREL has recommended that two smaller pumps be used in place of the current pump. These pumps should be installed in series to provide sufficient pressure head during start-up, after which time one pump could be turned off to reduce the flow.

The system start-up issue appeared to be a result of temperature readings that were not representative of the actual supply and return temperatures to the solar collector. The return temperature sensor on the collector was originally located outside of the collector on the return pipe. This sensor was moved to the back of the absorber plate inside the collector to better indicate the temperature of the empty collector when the system is off for a period of time. In addition, the sensor at the bottom of the stratified solar tank, which was supposed to measure the collector supply temperature, was actually providing readings closer to the average tank temperature. The temperature sensors providing these readings have been relocated since the time of the test, and it appears that the system is now operating as intended.

\section{ANNUAL ENERGY SIMULATIONS}

A computer model of the Discovery House was created using the DOE-2.2 hourly simulation program. Inputs to the model were derived from the design specifications, short-term test results, TRNSYS simulations, and appliance spreadsheet calculations presented earlier in this paper. Simulations were performed in accordance with the BA Performance Analysis Procedures [7]. Graphical representations of the model generated using eQuest are shown in Figures 12 and 13.

The Discovery House prototype was compared to three base case houses: the BA Benchmark (representing typical practice in the 1990s), Regional Standard Practice, and Builder Standard Practice. The key features of these three base cases and the prototype are summarized in Table 4. Builder Standard Practice and Regional Standard Practice were estimated based on inputs from McStain and our experience with other builders in central Colorado. Although the stated efficiency of the prototype air conditioner was SEER 19, we modeled it as an effective SEER 16.5 based on discussions with BSC, an examination of the HVAC components, and published data from Lennox.

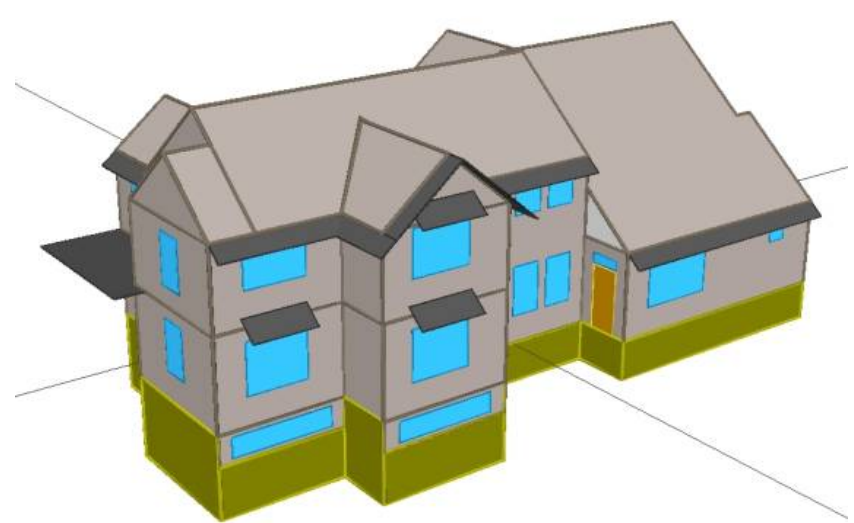

Figure 12. DOE-2 model geometry as viewed from the southwest, generated using eQuest

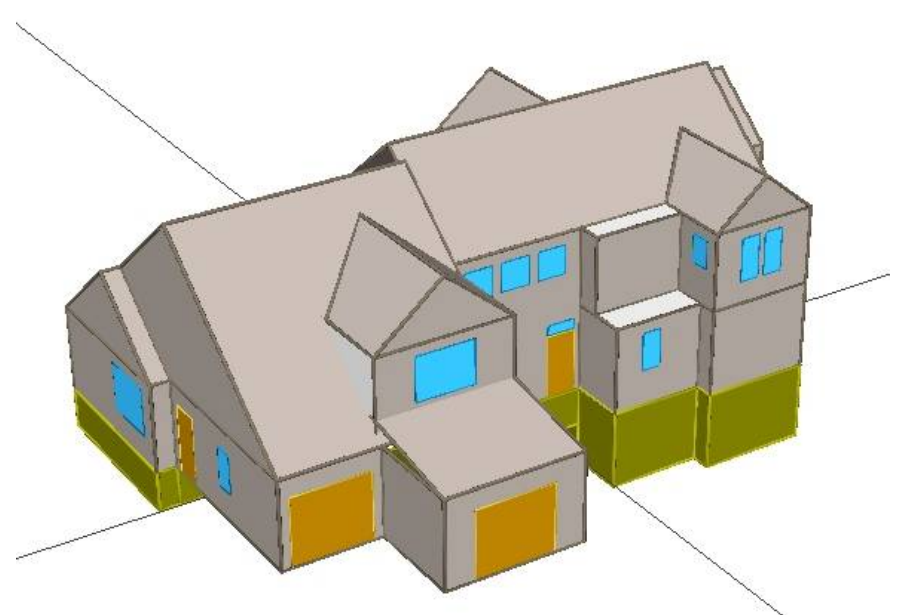

Figure 13. DOE-2 model geometry as viewed from the northeast with shading surfaces hidden, generated using eQuest

Table 4. Summary of model inputs for the Discovery House and three BA base cases

\section{BA Benchmark:}

Frame walls, 2x4, R-14 cavity insulation, wood siding

$\mathrm{R}-33$ ceiling insulation

Double-pane clear windows

Uninsulated vented crawlspace

R-10 basement walls

Infiltration rate $=0.65 \mathrm{ACH}$ (annual average)

10 SEER 4-ton (14 kW) air-conditioner

$78 \%$ AFUE forced-air furnace

40-gal (151-liter) Gas DHW, standard 0.54 EF

$90 \%$ incandescent lighting

Standard appliances

\section{Regional Standard Practice:}

Same as Benchmark except:

R-27 ceiling insulation

Uninsulated basement walls

Infiltration rate $=0.35 \mathrm{ACH}$ (annual average)

Builder Standard Practice:

Same as Regional Standard Practice except: 


Frame walls, $2 \times 6,16$ in $(41 \mathrm{~cm})$ oc, R-19 cavity insulation
R-38 ceiling insulation
Low-E, double-pane windows
Conditioned crawlspace and basement
R-5 insulated basement walls
Infiltration rate $<0.35$ ACH (annual average)
12-SEER air conditioner
92.1\% AFUE furnace
Power-vented gas DHW, 0.58 EF
ENERGY STAR refrigerator and dishwasher
Prototype (Discovery House):
Same as Builder Standard Practice except:
Frame walls, 24 in ( 61 cm) oc, sprayed cellulose insulation
R-4 insulating sheathing
R-11 insulated basement walls
R-44 ceiling insulation
Low-E, spectrally selective, vinyl frame windows
Infiltration rate = 0.1 ACH
75 cfm (35 1/s) HRV
Temperature-controlled natural ventilation
Movable awnings
16.5 SEER 3-ton (11 kW) air-conditioner
Active solar DHW system with 0.86 EF recovery backup
$90 \%$ AFUE boiler with solar assist
Radiant slab and forced-air distribution
$90 \%$ compact fluorescent lighting
All ENERGY STAR appliances

Source energy calculations sorted by end-use for the Discovery House prototype and base case houses are presented in Table 5. Source energy, or primary energy, is defined as the energy delivered to the house (site energy) plus the energy required for generation, transmission and distribution. The national average site-to-source energy multiplier for electricity is about 3.16, and for natural gas is about 1.02 [7]. Table 5 indicates that energy for space cooling and DHW are nearly eliminated. Space heating and lighting are also significantly reduced, and there is a noticeable reduction in appliance energy. Total source energy savings for the Discovery House compared to the Benchmark is predicted to be $54 \%$, significantly exceeding the design target of $40-50 \%$.

Estimated energy and cost savings for packages of efficiency measures are shown in Table 6. Descriptions of the measures included in each package are listed in Table 7 . The effect of each measure on end-use energy consumption is shown in Figure 14. A significant fraction of the total savings is attributable to the quality of construction that McStain has already implemented, as indicated by the bar labeled "Builder Std." Beyond McStain's standard features, the most significant energy savings are associated with the high-efficiency boiler, efficient air distribution, solar hot water system, HRV, and compact fluorescent lighting package.

As often happens in a showcase home with many pieces of equipment that are donated or intended to be more educational than cost-effective, the Discovery house has a few redundant energy efficiency measures. Low solar heat gain windows, exterior shading, high-SEER air conditioner, whole-house fan, and thermostatically controlled windows are all measures that reduce summertime cooling energy for a house that already has limited cooling loads because of a tight building envelope, heat recovery ventilation, efficient lighting and appliances, and a climate with relatively few cooling degree days. NREL performed some additional simulations in an attempt to identify a more cost-effective package, but the effect of each measure on annual energy use was heavily dependent on the sequence in which the measures were ordered. Other important considerations, including comfort, health and safety, durability, and physical appearance must also be factored into the trade-off analysis, along with energy and cost.

Table 5. Predicted Annual End-use Source Energy Consumption and Energy Savings for the McStain Discovery House

\begin{tabular}{|c|c|c|c|c|c|c|c|c|c|c|}
\hline & & & & & \multicolumn{6}{|c|}{ Annual Source Energy Savings } \\
\hline & \multicolumn{4}{|c|}{ Annual Source Energy } & \multicolumn{3}{|c|}{ Percent of End-Use } & \multicolumn{3}{|c|}{ Percent of Total } \\
\hline & $\begin{array}{c}\text { BA Bench } \\
\mathrm{kWh} / \mathrm{yr}\end{array}$ & $\begin{array}{l}\text { Region } \\
\mathrm{kWh} / \mathrm{yr}\end{array}$ & $\begin{array}{l}\text { Builder } \\
\mathrm{kWh} / \mathrm{yr}\end{array}$ & $\begin{array}{c}\text { Proto } \\
\mathrm{kWh} / \mathrm{yr}\end{array}$ & $\begin{array}{c}\text { BA } \\
\text { Bench }\end{array}$ & $\begin{array}{l}\text { Reg } \\
\text { Base }\end{array}$ & $\begin{array}{l}\text { Bldr } \\
\text { Base }\end{array}$ & $\begin{array}{c}\text { BA } \\
\text { Bench }\end{array}$ & $\begin{array}{l}\text { Reg } \\
\text { Base }\end{array}$ & $\begin{array}{l}\text { Bldr } \\
\text { Base } \\
\end{array}$ \\
\hline Space Heating & 53,932 & 38,303 & 33,554 & 20,881 & $61 \%$ & $45 \%$ & $38 \%$ & $33 \%$ & $22 \%$ & $18 \%$ \\
\hline Space Cooling & 9,520 & 3,583 & 2,617 & 1,036 & $89 \%$ & $71 \%$ & $60 \%$ & $8 \%$ & $3 \%$ & $2 \%$ \\
\hline DHW & 8,514 & 8,514 & 7,652 & 1,049 & $88 \%$ & $88 \%$ & $86 \%$ & $7 \%$ & $9 \%$ & $9 \%$ \\
\hline Lighting & 8,517 & 8,517 & 8,517 & 3,407 & $60 \%$ & $60 \%$ & $60 \%$ & $5 \%$ & $6 \%$ & $7 \%$ \\
\hline Appliances + Plug & 19,136 & 19,952 & 18,425 & 18,137 & $5 \%$ & $9 \%$ & $2 \%$ & $1 \%$ & $2 \%$ & $0 \%$ \\
\hline Ventilation & 651 & 651 & 651 & 2,048 & $-214 \%$ & $-214 \%$ & $-214 \%$ & $-1 \%$ & $-2 \%$ & $-2 \%$ \\
\hline Total Usage & 100,272 & 79,519 & 71,416 & 46,559 & $54 \%$ & $41 \%$ & $35 \%$ & $54 \%$ & $41 \%$ & $35 \%$ \\
\hline Site Generation & 0 & 0 & 0 & 0 & & & & $0 \%$ & $0 \%$ & $0 \%$ \\
\hline Net Energy Use & 100,272 & 79,519 & 71,416 & 46,559 & $54 \%$ & $44 \%$ & $35 \%$ & $54 \%$ & $41 \%$ & $35 \%$ \\
\hline
\end{tabular}


Table 6. Predicted Annual Energy and Cost Savings for Major Energy Efficiency Measures

\begin{tabular}{|c|c|c|c|c|c|c|c|c|c|}
\hline & \multirow[b]{2}{*}{$\begin{array}{c}\text { Annual Site } \\
\text { Energy }\end{array}$} & \multirow{2}{*}{\multicolumn{2}{|c|}{$\begin{array}{c}\text { Annual Source } \\
\text { Energy }\end{array}$}} & \multirow{2}{*}{\multicolumn{2}{|c|}{\begin{tabular}{|c|} 
National Average \\
Annual Energy \\
Cost
\end{tabular}}} & \multicolumn{4}{|c|}{ Builder Standard (Local Costs) } \\
\hline & & & & & & \multicolumn{2}{|c|}{$\begin{array}{c}\text { Annual Energy } \\
\text { Cost }\end{array}$} & \multicolumn{2}{|c|}{\begin{tabular}{|c|} 
Savings for Savings for \\
Measure Package
\end{tabular}} \\
\hline Increment & $\mathrm{kWh}$ & $\mathrm{kWh}$ & Savings & $\$ / y r$ & Savings & $\$ / \mathrm{yr}$ & Savings & value $(\$ / y r)$ & \\
\hline BA Benchmark & 65,658 & 100,357 & & $\$ 2,828$ & & $\$ 2,516$ & & & \\
\hline Regional Standard Practice & 51,599 & 79,556 & $21 \%$ & $\$ 2,244$ & $21 \%$ & $\$ 1,987$ & & & \\
\hline Builder Standard Practice & 45,943 & 71,459 & $29 \%$ & $\$ 2,016$ & $29 \%$ & $\$ 1,778$ & & & \\
\hline $\begin{array}{l}\text { Improved Wall and Ceiling } \\
\text { Insulation }\end{array}$ & 43,583 & 68,387 & $32 \%$ & $\$ 1,931$ & $32 \%$ & $\$ 1,695$ & $5 \%$ & $\$ 83$ & $\$ 83$ \\
\hline \begin{tabular}{|l} 
Basement Wall and \\
Crawlspace Ceiling Insulation.
\end{tabular} & 41,357 & 65,987 & $34 \%$ & $\$ 1,865$ & $34 \%$ & $\$ 1,624$ & $9 \%$ & $\$ 71$ & $\$ 154$ \\
\hline Automatic Exterior Shading & 41,477 & 66,026 & $34 \%$ & $\$ 1,866$ & $34 \%$ & $\$ 1,627$ & $9 \%$ & $\$(3)$ & $\$ 151$ \\
\hline Automatic Natural Ventilation & 41,855 & 66,196 & $34 \%$ & $\$ 1,870$ & $34 \%$ & $\$ 1,635$ & $8 \%$ & $\$(9)$ & $\$ 143$ \\
\hline HRV & 38,080 & 62,462 & $38 \%$ & $\$ 1,769$ & $37 \%$ & $\$ 1,519$ & $15 \%$ & $\$ 116$ & $\$ 259$ \\
\hline Improved DHW & 35,471 & 59,395 & $41 \%$ & $\$ 1,684$ & $40 \%$ & $\$ 1,432$ & $19 \%$ & $\$ 87$ & $\$ 346$ \\
\hline Improved HVAC & 31,000 & 53,679 & $47 \%$ & $\$ 1,525$ & $46 \%$ & $\$ 1,277$ & $28 \%$ & $\$ 156$ & $\$ 501$ \\
\hline Improved Cooling & 30,918 & 53,273 & $47 \%$ & $\$ 1,513$ & $47 \%$ & $\$ 1,270$ & $29 \%$ & $\$ 7$ & $\$ 508$ \\
\hline Solar DHW and Space Heat & 27,610 & 50,886 & $49 \%$ & $\$ 1,451$ & $49 \%$ & $\$ 1,181$ & $34 \%$ & $\$ 89$ & $\$ 597$ \\
\hline Lighting and Appliance & 26,889 & 46,633 & $54 \%$ & $\$ 1,325$ & $53 \%$ & $\$ 1,109$ & $38 \%$ & $\$ 72$ & $\$ 669$ \\
\hline
\end{tabular}

"Source Energy Savings \%" and "National Average Energy Cost Savings \%" are compared to the Building America Benchmark, whereas the "Local Energy Cost Savings \%" and the "Package savings \$/yr" are compared to Builder Standard Practice.

National Average Electric Cost: $\quad 0.087 \quad \$ / \mathrm{kWh}$

National Average Gas Cost: $\quad 0.032 \quad \$ / \mathrm{kWh}$

Local Average Electric Cost: $\quad 0.059 \quad \$ / \mathrm{kWh}$

Local Average Gas Cost: $\quad 0.033 \quad \$ / \mathrm{kWh}$

Table 7. Descriptions of Energy Efficiency Measures included in Each Step of the Analysis

\begin{tabular}{|l|l|}
\hline \multicolumn{1}{|c|}{ Measure } & \multicolumn{1}{c|}{ Description } \\
\hline BA Benchmark & $\begin{array}{l}\text { Establishes the baseline energy use for } \\
\text { the analysis. }\end{array}$ \\
\hline $\begin{array}{l}\text { Regional Standard } \\
\text { Practice }\end{array}$ & $\begin{array}{l}\text { Regional Standard Practice models a } \\
\text { building typical of the region }\end{array}$ \\
\hline $\begin{array}{l}\text { Builder Standard } \\
\text { Practice }\end{array}$ & $\begin{array}{l}\text { Builder Standard Practice models a } \\
\text { building typical of this builder }\end{array}$ \\
\hline $\begin{array}{l}\text { Improved Wall and } \\
\text { Ceiling Insulation }\end{array}$ & $\begin{array}{l}\text { Walls improved to R-27 (2x6 with R-4 } \\
\text { sheathing), Ceiling to R-44 }\end{array}$ \\
\hline $\begin{array}{l}\text { Basement Wall and } \\
\text { Crawlspace Ceiling } \\
\text { Insulation }\end{array}$ & $\begin{array}{l}\text { Basement wall insulation increased to R- } \\
11 \text { full length, Crawlspace Ceiling } \\
\text { insulation to R-15 }\end{array}$ \\
\hline Exterior Shading & Movable Shading added \\
\hline $\begin{array}{l}\text { Automatic Natural } \\
\text { Ventilation }\end{array}$ & $\begin{array}{l}\text { Automatically opening ventilation added } \\
\text { (windows) }\end{array}$ \\
\hline HRV & $\begin{array}{l}\text { 70\% Effective, 0.15 ACH HRV system } \\
\text { DHW improved to a boiler with } \\
\text { EF=0.86 }\end{array}$ \\
\hline Improved DHW & $\begin{array}{l}\text { Duct system 95\% efficiency, } \\
\text { electronically commutated fan motor, } \\
\text { downsized 3-ton (10.5-kW) A/C }\end{array}$ \\
\hline Improved HVAC
\end{tabular}

\begin{tabular}{|l|l|}
\hline Improved Cooling & Improved cooling system (SEER 16.5) \\
\hline $\begin{array}{l}\text { Solar DHW \& Space } \\
\text { Heat }\end{array}$ & $\begin{array}{l}\text { Active solar hot water system supplies } \\
\text { heat to DHW and space heat }\end{array}$ \\
\hline Lighting \& Appliance & CFLs, Energy-Star appliances, \\
\hline
\end{tabular}

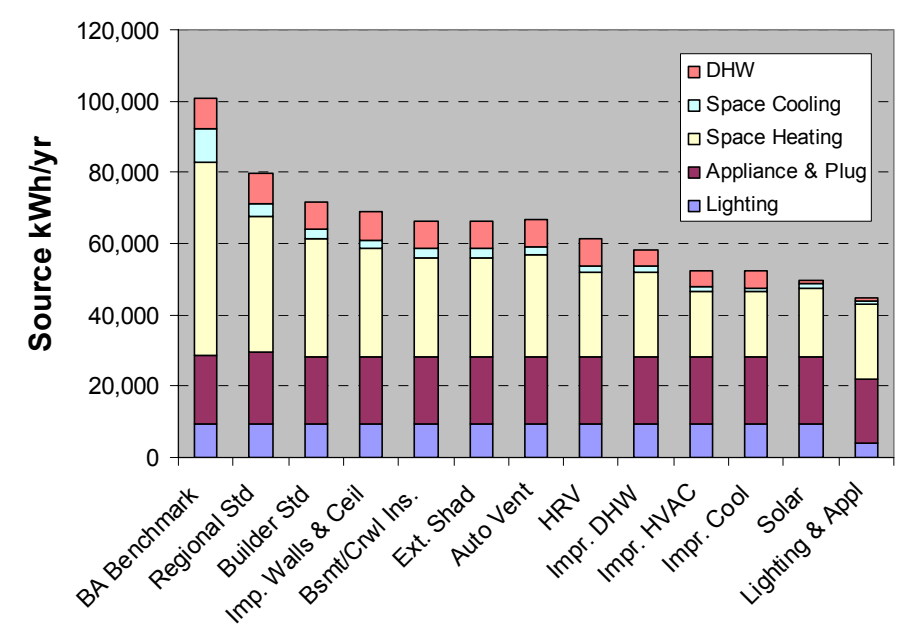

Figure 14. Influence of efficiency measures on end-use energy consumption 


\section{LONG-TERM MONITORING}

NREL plans to record detailed measurements at short time intervals over an extended period of time to provide insights and interpretations that are not available from short-term testing, simulations, or monthly utility bills. The results of this long-term monitoring program (including direct measurements, utility bills, and homeowner interviews) will be documented in a follow-up paper.

\section{CONCLUSIONS}

Based on the test and analytical results discussed in the preceding sections, we were able to draw several conclusions:

- The building envelope of the Discovery House was very tight. Tracer-gas testing indicated about 0.02 to $0.05 \mathrm{ACH}$ during mild summer weather. Blower-door tests conducted by BSC suggested an annual average infiltration of 0.16 $\mathrm{ACH}$.

- Duct leakage to the outside was well within the design goal of $60 \mathrm{cfm}(28 \mathrm{l} / \mathrm{s})$ at $25 \mathrm{~Pa}$, as measured by BSC using a duct blaster. Tracer-gas test results were consistent with duct-blaster measurements, indicating that duct leakage was less than $12 \mathrm{cfm}(6 \mathrm{l} / \mathrm{s})$ to the outside while the air handler was operating. NREL did not evaluate total duct leakage, but duct-blaster testing by BSC showed it to be slightly higher than the design goal.

- Based on tracer-gas measurements, the HRV provided fresh air at a rate of about $75 \mathrm{cfm}(35 \mathrm{l} / \mathrm{s})$ when operating at low speed, consistent with the recommendations of ASHRAE Standard 62.2.

- The dishwasher, clothes washer, and clothes dryer each consumed significantly less energy than the BA Benchmark under normal operating conditions. However, certain operating modes, including the "sanitary" clothes washer cycle and the dishwasher power-dry option, used much more machine energy and/or hot water than other operating modes. The soil sensor in the dishwasher also dramatically increased energy use, while the weight sensor in the clothes washer significantly reduced energy use.

- The solar hot water system is expected to meet a large fraction of the DHW load ( 83\%), but only about $12 \%$ of the space-heating load. We recommended that the air handler heating coil loop be re-plumbed so that it is not allowed to circulate through the solar storage tank. The storage tank temperature setting could then be lowered to $90^{\circ} \mathrm{F}\left(32^{\circ} \mathrm{C}\right)$, and the basement hydronic loop could make greater use of the solar-heated water.

- DOE-2.2 simulations predict whole-house source energy savings of $54 \%$ compared to the BA Benchmark. The largest contributors to the energy savings (other than the efficiency improvements that are already standard practice for McStain) are the solar water heater, high-efficiency boiler, air-distribution improvements, HRV, and compact fluorescent lighting package.

- The measures designed to reduce cooling energy (including a high SEER air conditioner, exterior shading, low solar heat gain glass, heat recovery ventilation, tight envelope, automatic window control, and night ventilation) appear to be a bit redundant given the relatively mild summertime weather in Loveland. However, because the benefits of each measure are dependent on the order in which the measures are analyzed, it is difficult to say which are most cost-effective. It is also important to note that occupant comfort, durability, and other considerations must factor into the decision-making process when evaluating these features.

\section{ACKNOWLEDGMENTS}

We express our appreciation to Justin Wilson, Jeff Medanich, and the rest of the team at McStain Neighborhoods for providing NREL with extensive field support, including generous access to the Discovery House during and after the test period. We would also like to acknowledge the hard work of the BSC team in assisting with the design of the Discovery House and offering their insights throughout the test and analysis phase of the project. Finally, we want to thank Ed Pollock and George James of DOE for the leadership and resources necessary to perform this work.

\section{REFERENCES}

[1] Hendron, R. 2005. Building America Research Benchmark Definition, Updated December 29, 2004. NREL Report No. 37529, Golden, CO: National Renewable Energy Laboratory.

[2] McStain Neighborhoods. 2004. The McStain Discovery House Breaks Ground! Louisville, CO.

[3] Eastment, M., Hendron, R. In Preparation. Method for Evaluating Energy Use of Dishwashers, Clotheswashers and Clothes Dryers Based on DOE Test Procedures. Draft NREL Technical Report.

[4] U.S. Department of Energy (DOE). 2001. Code of Federal Regulations Title 10, Part 430, Subpart B, Appendix J Uniform Test Method for Measuring the Energy Consumption of Automatic and Semi-automatic Clothes Washers, DOE, Washington, DC.

[5] U.S. Department of Energy (DOE). 1981. Code of Federal Regulations Title 10, Part 430, Subpart B, Appendix D Uniform Test Method for Measuring Energy Consumption of Clothes Dryers, DOE, Washington, DC.

[6] U.S. Department of Energy (DOE). 2003. Code of Federal Regulations Title 10, Part 430, Subpart B, Appendix C Uniform Test Method for Measuring Energy Consumption of Dishwashers, DOE, Washington, DC.

[7] Hendron, R., Anderson, R., Judkoff, R., Christensen, C., Eastment, M., Norton, P., Reeves, P., Hancock, E. 2004. Building America Performance Analysis Procedures: Revision 1. NREL Report No. TP-550-35567, Golden, CO: National Renewable Energy Laboratory. 